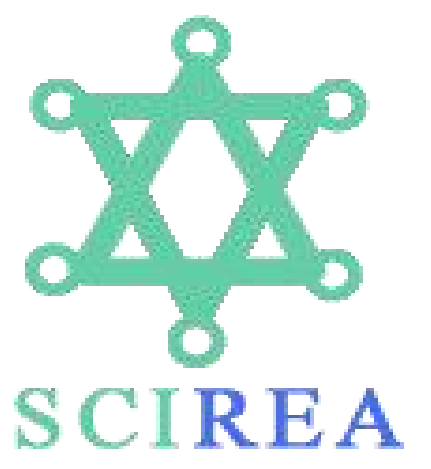

SCIREA Journal of Sociology

http://www.scirea.org/journal/Sociology

January 20, 2022

Volume 6, Issue 1, February 2022

https://doi.org/10.54647/sociology 84734

\title{
Iran, China and Russia: in Strategic Partnership
}

\author{
Adam Tarock \\ University of Melbourne (retired), Australia
}

\begin{abstract}
Iran, Russia and China have formed a partnership which has served their geopolitical and economic interests very well over the years. This partnership would most probably have not formed, had it not been for the U.S. relentless hostility directed against the trio in recent decades. This article discusses and analyses the trio's historical ties, but giving greater emphasis to more recent developments. In the Trump era, however, the hostility between Teheran and Washington heightened to the extent that a U.S. military attack against Iran was no longer unthinkable. The intensity of hostility is at present abated, but the U.S. change of regime in Iran still remains on the table. In such an eventuality, neither of the two major world powers is likely to come directly to Iran's rescue, but they can make it very difficult for the U.S. to defeat Iran as quickly and as easily as Washington invaded Afghanistan, Iraq and Libya. As is discussed here, Iran is too important for both Moscow and Beijing to let their junior partner become a U.S. surrogate.
\end{abstract}

Keywords: alliance, weakest link, oil, Russia, arms sales, investments and Putin. 
When the guard at the White House changed, in January 2021, from President Donald Trump, the architect of the maximum economic and political pressure on Iran and intensifying tensions between Washington and its great rivals Russia and China, to the perceived accommodating and inclusive President Joe Biden, there were hopes of better relations between the trio and the U.S. old adversaries. But Biden's continuation of hardline policy towards Iran has made it clear that the old conflict between the two countries will continue, at Iran's expense. That is why the Islamic Republic of Iran's partnership with the other two major world powers, the Russian Federation and the People's Republic of China, is so important not only for Iran but has also implications for the world. The friendship and rejection of the U/S. is rested on two pillars: (a) on their rejection of the international liberal order, a theory which argues how a dominant power can organise the world and require that other states recognise the universality of its dominance and sole leadership, a leadership that the U.S. has arrogated to itself since the end of the Cold War. And (b), the rejection of the U/S. dominance in the three countries is based on historical and cultural feelings that each of them has once been a great and independent centre of power and should not tolerate the dictate of a foreign power.

A cursory look at the trio's partnership appears to be atypical because of the vast differences in their historical, cultural and ideological backgrounds and of their geographical locations. But from a political and geostrategic point of view, the partnership is indeed 'natural' in the proverbial sense that the enemy of my enemy is my friend. The three countries have been targets of the U.S. hostility and subjected to political and economic pressures for years. And there is at present no evidence that the status of the relationship between them and the U.S. would dramatically change anytime soon. Of the trio, Iran is the weakest link from economic and military perspectives, yet it enjoys the capability of contributing much to the partnership. Iran's geopolitical location, its cultural influence in the Middle East and Central Asia, its rich natural resources and its educated human manpower are all very important to the other two partners (more of Iran's political contributions to the partnership later). A particularly significant factor for fostering the alliance has been the entente between China and Russia under the leadership of Vladimir Putin and Secretary General Xi Jinping. The new period in their relations began because of entirely new factors that emerged after Russia entered into serious conflict with the West in 2014, and the United States launched a trade war against China in 2016. These events proved to both countries that the United States and its Western allies would never accept them as equal. For Iran, this harmony between Russia and China - 
after their great split in the 1950s-60s and their continued squabbling for some decades later must have been a welcome development. Teheran must have viewed the Russia-China entente as a blessing for it has provided a protective shield, however tenuous and uncertain, against the relentless threats to Iran's very existence from the United States' devastating economic sanctions and its long-held plan to change the Iranian government. Iran has on many occasions warmly welcomed visits of presidents of Russia and China to Teheran in recent years. Those visits, as we will see later, have strengthened the bond between them.

To understand the main reasons for Washington's hardline policy towards the three countries, one has to go back to a U.S. National Security Strategy report put out by Defense Department after the end of the Cold War. The essence of that policy report stands today as it was conceived then. The report classified China and Russia as revisionist powers. 'We assumed [after the end of Cold War] that our military superiority was guaranteed and that a democratic peace was inevitable....' It is, therefore reasonable to deduce from the report that Washington's difficulty with Moscow, Beijing (and the Islamic Republic) comes from the fact that they have been to a good degree successful in asserting themselves in the international arena. The spirit of the report is reflected in the foreign policy of the Trump administration's repeated slogans affirming 'America First,' 'Make America Great Again' and 'American exceptionalism.' The U.S. self-importance (arrogance?) is understandable, considering that Washington has been accustomed since the end of the Cold War to be globally predominant. By now, Washington finds it hard to accommodate challengers and rivals.

This paper is divided into two parts. The first part is a discussion about relations between Teheran and Beijing prior to and since the establishment of the Islamic Republic in 1979. It explains how their relations began to blossom during the Iran-Iraq war in the 1980s when the war was going very badly for Teheran because of the shortage of military equipment. Unlike most other major world powers, including the then Soviet Union, China agreed to supply arms to Iran. That has left indelible positive impacts on the Iranian leadership and the Iranian public. That 'good-will' set the foundation of the Sino-Iranian relations as they are at the present. Today, Iranian foreign policy places particular significance on its ties with China. Part two discusses Iran-Russia relations, covering, briefly, the periods before and since the demise of the Soviet Union in 1991. It will be argued that in contrast to the Iran-China story, Iran's relations with its old neighbour, first Tsarist Russia and then the Soviet Union, has been, more often than not, acrimonious. They fought two major wars in the nineteenth century, with

\footnotetext{
${ }^{1}$-Susan Watkins, in New Left Review, “America vs China," 2019, No. 115, 1.
} 
Iran losing vast territories to Russia. And in the twentieth century, there were almost continuous tensions between the two during the Cold War era. In its anti-Iran propaganda, Moscow often explicitly threatened Teheran with military action. This paper will then go on to explore how much, and to what extent, the two countries' cooperation has been expanded since the collapse of the Soviet Union. In discussing Iran's expanded ties with China and Russia, and in view of Washington's ongoing hardline policy towards Teheran, the two major world powers referred to above can, and do, provide psychological support, as well as political, technological, economic and military assistance to Iran. It is argued here that China and Russia can, metaphorically speaking, shield Iran from the claws of the 'American Eagle'.

\section{China-Iran convivial relations}

Discussions about Iran and China relations often begins with citing from history. According to history, the two countries' ties go back more than two thousand years. The routes of their human contacts, cultural activities, social and trade exchanges were through the Silk Road. Geography allowed successive dynastic empires on both sides to pursue enough interaction in trade and peoples' contacts, yet far enough separated by hostile terrains that they never clashed or competed, plundered, or coveted each other's territories. They could not do so because their huge geographical distance would not allow them. But both have had bitter experience of Western domination, for which they paid a heavy price in blood and treasure to regain their independence and sovereignty. The similarity of their historical experiences and struggle has helped them in modern times to form an affinity that has come from their national consciousness, and mutual intellectual empathy. Although in international relations human emotions do not, or should not, count for much, yet in politics national and human emotions cannot be discounted lightly either. To Westerners, these sorts of historical ruminations may sound banal and passé. In short, history weighs heavily in both countries; for them, the exposition of historical symbolism plays an important cultural identity and affinity in the consciousness of the two peoples. As for the present time, both countries are targets, for different reasons and to different degrees, of the U.S. hostility.

In more recent time, the diplomatic contacts between Iran and China began, cautiously, in the early 1960s. At the time, the Shah was in full control of almost all aspects of Iranian domestic and foreign affairs. So, he began to make diplomatic contact with Communist China. However, Iranian officials and the media, having during the Cold War era portrayed the 
country as a threat to Iran's national security, treated the opening of relations with Beijing discreetly and timidly. The reason for their reservation towards China was because of ideological, though not necessarily political, affinity between Moscow and Beijing. The former country, an immediate neighbour of Iran then, had for decades been agitating, through radio programmes beamed at the Iranians, to try to overthrow the Pahlavi monarchy. This, in turn, had resulted in outlawing all the leftist parties in Iran, in particular the Tudeh (communist) Party, Hence Iran's cautious approach to China. At the time that Teheran was approaching Beijing, relations between the Soviet Union and China had split because of differences in the early 1950s. The Cold War was then still very hot in the East-West relationship, and Iran had remained firmly in the Western camp and, therefore it could not have an overtly cozy relationship with Beijing. However, from the early 1970s, Iran's policy changed and the Iranian policymakers took bolder steps towards China. The catalyst for the change in Teheran's policy was a U.S.-China tennis match in April 1971, which resulted in thawing relations between Washington and Beijing and hence paving the way for Iran-China rapprochement.

Another important reason for the rapprochement was that the Iranians believed good and friendly relations with Beijing could serve as a balancing act with Moscow. To the Iranians, the rift between the two great communist powers was rooted in history, geography, race and ethnicity, and therefore, it was thought, Soviet communism differed fundamentally from Chinese communism; in that the latter did not seek to build an empire by the acquisition and occupation of other people's land, as did the Soviet Union. ${ }^{2}$ There was at the time a small group of leftist Iranian dissidents and intellectuals and some high-ranking officials who advocated more active diplomatic and economic ties between China and Iran. They argued that unlike the Soviet Union and the West, China did not have the missionary zeal to motivate them to preach and lecture other nations on the merits of communism and/or values of the Chinese civilisation and culture. Nor did the Chinese, unlike the U.S., have a desire to operate in a world of like-minded states, that is pushing for regime change of other countries in the guise of democracy, so went the argument.

In parenthesis, it is worth noting that the Shah's interest in expanding relations with China was mostly political and not technical and/or economic. In the early 1970s, China was still far from being a developed and technologically advanced country, as it became later. It should also be remembered that in the 1960s and 1970s, Iran, flushed with billions from oil revenue,

\footnotetext{
2 - Ghlam Reza Afkhami, Life of the Shah, University of California Press, 2009, 296.
} 
had embarked on huge industrial and technological projects and was looking Westward, and not Eastward, for scientific and technological assistance. Still, China was admired by many developing countries for its relatively high technological development that it had reached in a short span of time. So, some Iranian technocrats and economists argued that the country should follow the Chinese model of development: that is, to start with low level technologies and gradually move upward as one learned. Following the Chinese model, it was thought, would free Iran from always going to the West with cap in hand for new technologies. The technocrats further argued that historically the West had rarely shown interest, let alone genuine commitment, to Iran's development. However, others economists maintained that the country should adopt the Japanese model, it being to take Western technologies and gradually make them 'native.' The Shah who was ideologically Westward looking opted for the Japanese model, according to Afkhami. ${ }^{3}$ (Incidentally, it has been the Chinese model that the Islamic Republic has adopted to develop Iran's development projects in areas such nuclear energy, missiles, industrial projects, agriculture, military and other fields.)

In any case, the Shah sent Queen Farah to Beijing in 1972, more as a goodwill envoy rather than as a political one. She was warmly received by the Chinese. Shortly after her visit, Prime Minister Amir Abbas Hoveyda paid an official visit to Beijing. To further upgrade their relationship, China in August 1979 sent to Teheran Hua Gufeng, then China's premier and chairman of the Communist Party. As it happened, the timing of his visit was very inauspicious. It was when the Iranian revolution was near its final stages of victory, and only a couple of months before the Shah was forced out of the country. The revolutionaries interpreted the visit as China's endorsing the Pahlavi monarchy, and so the Ayatollah Ruhollah Khomeini, initially did not 'forgive such a transgression' by the Chinese government, implying that Beijing was as 'imperialist' as the United States and the Soviet Union. Thus, Hua's visit proved embarrassing to the Chinese; so after the success of the revolution, they said that Mr. Hua's visit to Teheran was a stopover only. ${ }^{4}$

To prove their point, the Chinese recognised the Islamic Republic of Iran three days after it was officially established. The Chinese explanation and the quick recognition of the new government in Teheran were apparently satisfactory enough for the Iranian authorities. It could also reasonably be argued that Teheran must have been pleased with Beijing's overtures,

\footnotetext{
${ }^{3}$ Afkhami, The Life of, 206.

${ }^{4}$ Scott Harold and Alireza Nader, "China and Iran: Economic. Political and Military Cooperation,; RAND Corporation, Centre for Middle East Public Policy, 2012, p.
} 
as at the time the Islamic Republic was shunned by most Western and some non-Western countries. It is well to recall that China's recognition of the new government in Teheran coincided with the U.S. and Israel's military threats; it also coincided with Saddam Hussein's invasion of Iran in September 1980. While the above analyses are correct, the Islamic Republic's desire for opening up to China was something more fundamental. China by the 1970s was speaking of 'mutually beneficial' arrangements such as the principles of peaceful coexistence: no interference in the internal affairs of other countries; respect for the principle of international law; and the fundamental difference between the foreign policy of Beijing and that of the hegemonic polices persuade by other major powers, especially by the United States. To put it differently China (and Russia) no longer held any illusions that Washington would treat it as an equal partner. ${ }^{5}$ The 1980 s happened also to be a period when China had reversed the Maoist economic development strategy by committing itself to free trade and had opened up to the outside world. To put it differently, China had come out of the cold by the end of the 1980s. In scholarly literature, this phase of modern Chinese is referred to as China's 'ascent' in the international arena. ${ }^{6}$

\section{Expansion of trade}

Iranian relations with China began expanding rapidly in many fields after the end of the 1980s. The expansions included in areas such as political cooperation, economic, military (sales of arms) and technical assistance from the Chinese side; on the Iranian side, it included mostly the sale of oil and related oil products. For China, it is very important to continue importing oil from Iran. The most obvious reason is, naturally enough, because of its high rapid expansion in the manufacturing sector, and its other industrial and economic programmes. China's evermore needs for oil and its determination to keep oil coming in is reflected in the fact that despite the strict ban imposed by the U.S., on the importation of Iranian oil, a Chinese tanker, in June 2019, carried two million barrels of Iranian oil for Beijing. ${ }^{7}$. To further demonstrate its determination to continue buying Iranian oil, Beijing imported yet more oil from Iran in early July of the same year. Iranian oil, by the way, is relatively cheap

\footnotetext{
${ }^{5}$ Alexander Kukin, "Have We Past the Peak of Sino-Russian Rapprochement," The Washington Quarterly, September 2021, 137.

${ }^{6}$ Harold and Nader, 2012, 3.

${ }^{7}$ Esfandyar Batmangholidj, “China Restarts Purchase Iranian Oil: Bucking Trump's Sanctions.” Bourse and Bazaar," :twitter.com ,17 June 2019.
} 
and of a quality that suits Chinese refineries. In general, China has over the past two and a half decades emerged as Iran's leading trade partner and Iran's largest oil customer. Beijing remains the only country buying Iranian oil - despite the U.S. oil sanctions. Foreign exchange revenues earned from the sale of oil are spent on high-value industrial inputs as well as finished goods such as consumer products. China is also a major industrial supplier to Iran, replacing the latter's traditional industrial supplier, the EU, since 2008. China's industrial sales include industrial parts and machinery Chinese exports to Iran rose from $\$ 2.5$ billion in 2004 to $\$ 14$ billion in $2018 .^{8}$ It should also be noted that China's trade volume and investments in the country has suffered a setback since the U.S. maximum pressure was put into effect.

Another significant aspect of the two countries' cooperation is in the field of arms sales and joint military exercises. As pointed out earlier, during the Iran-Iraq War China's arms sales to Iran reached a very high point of $\$ 3,3$ billion by the end of the war. And since the beginning of this century, China's sales of arms to Iran have included anti-ship missiles, portable surface to air missile systems. And finally, the two countries have conducted joint naval exercises in one of which Chinese warship, including the missile destroyer, Changchun, visited the Iranian Port Bandar Abbas. The third joint naval exercise took place, this time with the Russia, in December 2019. The point to stress here is that as the Chinese sale of weapons to Iran during the Iran-Iraq war (1980-8) was viewed by the Iranians as a 'gift,' so is now the Chinese purchase of banned Iranian oil. According to Jon Alterman, in 2009 China imported \$13.7 billion worth of crude oil; by 2010 that number had risen to $\$ 127$ billion. ${ }^{9}$ Also, the fact that Iran is located along China's Belt and Roads policy is important for both countries. What all that means is that to China, Washington's attempts to strangulate Iran economically could result in a change of government in Teheran. That change, if instigated by Washington, would almost certainly change the geopolitical landscape of the entire Middle East, a development that neither Russia nor China are likely to welcome. Such a change would further enhance Washington's influence in the region.

To further get a general sense of Iran's geopolitical and economic importance to China, and indeed to the world, it is worth elaborating here on the vast energy sources that the country enjoys. According to the Iranian National Oil Company (NIOC), the country's recoverable

\footnotetext{
${ }^{8}$ United States Institute of Peace, "Last Among Equals," (the Iran primer), 6 October 2020.

${ }^{9}$ Jon B. A. Alterman, "Chines and Russian Influence in the Middle East," Middle East Policy, Vol. 26, No.2, 2019.
} 
liquid hydrocarbon (oil and gas) reserves stand at about 160 billion barrels of oil, and 33.33 trillion cubic meters of gas. That includes the sixty-five oil and gas fields which have been discovered since 1979. On top of that, we should include the hydrocarbon reserve discoveries in the South Pars Gas Field, which is shared with Qatar. The offshore field is the largest gas field in the world, again according to the NIOC. Iran's oil exports to China had reached $\$ 24 \mathrm{~b}$ by $2018 .{ }^{10}$ (Iran Daily, 2018), a year before harsher trade restrictions were imposed on Teheran. At present, it is unclear how exactly Beijing will maneuver its way out between its commercial and strategic partnership with Teheran and its trade war with Washington. But it is likely that China will resist a total ban on the importation of Iranian oil and gas, or its lucrative trade. China, as we know, has become the principal driver of oil-demand growth around the world. For instance, in 2000 it imported $\$ 13.7$ billion worth of crude oil; by 2010 that number had risen to $\$ 127$ billion of crude oil - and was expected to rise incrementally. It is true that importation of any oil short fall from Iran can be compensated by other oil producing countries in the Middle East. The question for China, and indeed for other countries, is if they allowed the U.S. to determine for them to ban or not to ban trade with Iran, then the U.S. can also in the future determine for them the extent of their trade relations with countries that the U.S. happens to like or dislike.

One of the attractive features of a resurgent China to the Iranians is, that the former is untainted by imperial and territorial ambitions and forced acquisition of somebody else's land. The Iranians believe that unlike its imperial past and also unlike Western powers, the resurgent China, in dealing with other countries, has not tried to disrupt the social values of other societies. Nor has it, so goes the argument, tried to change governments and regimes that it does not like because of their particular sociopolitical complexions. Nor does it concern itself with fostering and/or imposing democracy, human rights, women's rights and other values on other peoples. In other words, in dealing with Iran, China has not been interested in either the internal or external policy and conduct of the Islamic Republic. That may appear a benign and exaggerated goodwill view of Beijing. But that is how the Iranians view present day China. This alignment of views between the two countries comes largely because of their mutual worldviews of Washington. Again, according to Alterman, Iran's foreign policy of rejecting the U.S. stance on unilateralism in international relations corresponds to that of China. Furthermore, tensions between the U.S. and Iran, Alterman goes on to argue, help to ensure that the latter cannot fully focus its military attention on the western Pacific. If, for

\footnotetext{
${ }^{10}$ Iran Daily, “Official: Iran-China Trade to Reach \$24 Billion in 2018,” 11 September 2018
} 
instance, the United States puts two carrier strike groups off the coast of Iran, and it can only fit three on a station at any given time, that means Washington only has one it can dedicate to China. Also, the U.S.-Iran military incidents from time to time in the Persian Gulf would in turn strain Washington's ties with its European allies, a development that Beijing would see as weakening the American global leadership.

\section{Iran going Eastward}

How did the West, perhaps inadvertently, pushed Iran Eastward? After the end of the IranIraq war in September 1988, Iran required a great deal of foreign investment and technical assistance from the outside world to reconstruct what was destroyed during the war. So, Teheran first turned to its traditional and much preferred European trading and economic partners. It also offered an olive branch to the United States to open a way for reconciliation between the two counties and to heal their mutually injured national pride. For example, as a goodwill gesture, Teheran contracted the U.S. oil company Conoco to explore and exploit oil in Iran, but the Clinton administration nullified the contract arguing that it was against the interests of the U.S.. European countries, however, showed willingness to participate (and they did) in the country's reconstruction programmes, but not to the extent that the Iranians had expected and hoped. So, what was left for Iran to do was look Eastward to countries such as India, Brazil, and particularly Russia and China.

The latter two countries have since been major traders and importers of Iranian oil and investors in Iran. China's trade and investment have included building Iran's infrastructure such as electricity, dams, cement plants, steel mills, shipbuilding, motorways, airports and supplies of consumer goods. ${ }^{11}$ But perhaps the most significant aspect of their cooperation is in the field of oil and natural gas, of which Iran has plenty. Petrochemical and non-metal minerals were among Iran's main exports to China in 2018. Iran's particular commercial attraction to China (and to other oil consuming countries) is its vast oil reserves, as well as its newly discovered energy resources as yet to be explored. In 2011, Iran held an Oil Show to attract foreign investment, one hundred and sixty-six Chinese companies, the largest number of foreign companies, attended the Oil Show. Iran has also formed a joint oil and gas committee with China to broaden and expedite energy cooperation. Further, China signed

\footnotetext{
${ }^{11}$ Dina Esfandiary and Ariane Tabatabai, Moscow and Bejing Have Teheran's Back," Foreign Policy, 26 July 2018.
} 
with Iran, in May 2011, a \$20 billion agreement to boost bilateral cooperation in the Iranian industrial and mining sectors. According to the Iran-China Chamber of Commerce Industries, trade between the two countries witnessed a twelve percent increase to $\$ 42$ billion by the end of 2018. That was a year after the Trump administration withdrew from the Iran nuclear deal. Since then, the volume of trade between the two countries has been reduced because of the U.S. secondary sanctions on countries that continue to trade with Iran.

To highlight their cooperation, Iran and China confirmed, in May 2020, a memorandum of understanding for a period of twenty-five years. According to the memorandum, the two countries would further expand economic, political and military cooperation between them. The nw arrangement, called Comprehensive Strategic Partnership, seeks to increase military, defence, security cooperation and investments in the Iranian oil industries. China, it is understood, will be able to buy Iranian oil and gas at an eighteen percent discount, and will be paying for it in soft and not hard currencies (like the U.S. dollar, the Euro and the Japanese yen). In other words, China will get its energy from Iran at a much lower market price. In fact, at present Iran has no other choice but to accommodate its foreign customers. In return, Beijing will invest in Iran $\$ 400$ billion for the duration of the agreement. The projects that China will invest in include construction of factories, infrastructures like hydrocarbon, a 560mile electrified rail link between Teheran and the southern city of Mashhad. China also hopes to link Mashhad to Central Asia and Europe through new high speed rail links, of which Iran will be a meeting point. Critics of the pact have argued that the figure $\$ 400$ million is not enough to raise the level of the economic standard that Iran enjoyed prior to the U.S. sanctions. ${ }^{12}$

Having said all that, it should also be said that the Iranians have no illusion about disloyalty that is a feature of international politics. They have had a long and bitter memory and experience with the insincerity, duplicity and fragility with which great powers can, and do, play politics. To put it differently, they understand that the present conflict between China and the U.S. could ameliorate anytime and affect negatively the present good relations between Teheran and Beijing. In other words, Beijing, despite its high standing in international arena, is still vulnerable to pressure from Washington. In fact, that is what happened in summer 2010 when the Obama administration worked hard to pass a UN Security Council sanctions resolution against Iran. In order to 'bribe' both China and Russia, President Obama offered

\footnotetext{
${ }^{12}$ Juan Cole, "How Trump Lost Iran to China -25 Years: Lion-Dragon Deal Makes Iran Part of One Belt, One Road," www.informedcomments.org 7 August 2020.
} 
the Russians a quid pro quo in exchange for a deal on the expiring of Strategic Arms Reduction Treaty and postponing the U.S. deployment of anti-missile systems in Europe. Thus, Russia agreed to the imposition of sanctions against Iran. In addition, the U.S. twisted China's arm over its alleged currency manipulation and threatened to harm China financially if it did not agree to sanction Iran, according to Susan Fayazmanesh, ${ }^{13}$ Teheran is mindful of the inconsistency and uncertainty of international politics. But such trade-off deals, however, could also cost Washington dearly when the latter would have to oblige Moscow and Beijing in other deals. ${ }^{14}$

Still, things do not look very bleak for Iran. The increasing trade war and strategic rivalry between Washington and Beijing in the Pacific region and Africa in recent years has obliquely helped further cement the Teheran-Beijing ties. Iran's value to China (and to Russia), however, cannot be measured only by the volume of trade, investment and access to Iran's vast oil and natural gas resources. Iran's geographical location, geopolitical and cultural influence in both the Greater Middle East and Central Asia are also of great value and attraction to the outsiders, both friends and foes. To put it differently, Iran has been, and is, in a position to act as an enabler of Chinese (and Russians) interests in those regions. So, Iran seems to have secured a special place in China's foreign policy. This is to a large part because of Iran's resistance and opposition to the U.S. political and military influence there. China views Iran as a capable and reliable challenger to U.S. power in region and it is free of Washington's dominance.

But what Beijing can do for Iran, and most likely would do is, among other things, use its political muscle at the U.N and other international forums to frustrate the U.S. anti-Iran plans. For example, China and Russia, along with others members of the U.N. Security Council defeated, in August 2020, the U.S. proposal for the continuation of arms embargo that was imposed on Teheran prior to the signing of the Iran nuclear deal. Pleased with China's move at the U.N., Iranian officials were quoted as saying, 'Teheran-Beijing ties are strategic and their prospects are bright... and that China's interests are closely tied to that of Iran.' 15 Another country that could make it difficult, short of direct military action, for the U.S. to attack Iran is Russia.

\footnotetext{
${ }^{13}$ Susan Fayazmanesh, " The U.S. Sanctions Are Affecting All Aspects of Iranian Life in Iran," www.counterpuch.org 1 August 2019.

${ }^{14}$ Harold and Nader, 2012.

${ }^{15}$ Pars News Agency, "Senior Analyst Underline’s Irn's Geostrategic Importance to China," 20 June 2021.
} 


\section{Ebbs and flows in Iran-Russia ties}

Unlike the Iran-China historical ties, the story of relations between Iran and the Tsarist Russia/the Soviet Union has gone through some very unfortunate, bitter and acrimonious experiences. Russia and Persia/Iran have had eight hundred years of political tensions and wars. In modern times, their conflicts started in the nineteenth century and continued until the demise of the Soviet Union in 1991. A brief discussion here of their historical relationship would help us to better understand and appreciate their present very amicable cooperation. We cannot fully understand their current relationship without first discussing their bitter, particularly on the Iranian side, history. In parenthesis, it is worth mentioning here that it was partly the remembering of those bitter memories that in much of the twentieth century Iran placed itself in the Western camp. The two countries went to war twice in the nineteenth century (1804-1813). According to historians, the wars were instigated by the Russian Empire. The wars ended in total disaster for Persia, which lost vast territories to the enemy. ${ }^{16}$ Persia was thus left with indelible hostility and distrust not only towards Russia, but also towards most great powers. something that has remained to the present time. As if all that were not bad enough, in the twentieth century Russia and Britain divided the country, in 1907, into their 'spheres of influence' in the Anglo-Russian Convention. To add insult to injury, after the end of World War II, the Soviets who, along with British and Americans, had occupied Iran during the war, refused to leave the Iranian province of Azerbaijan.

In refusing to leave Iran's Azerbaijan province, as the allies had agreed, the Soviets had apparently two objectives to achieve. The first was to annex the province to the Soviet Union; the second was to pressure Teheran to grant Moscow concessions for oil explorations similar to the oil concessions that Iran had given many decades earlier, to the Anglo Persian Oil Company (the present BP). In the end, Iran, supported by the West, took the matter to the United Nations and demanded Moscow stop interfering in the internal affairs of Iran and to withdraw its troops from the country. However, while the diplomatic negotiations were underway at the U.N., Teheran and Moscow engaged in direct talks and resolved the issue between themselves, with the Russians agreeing to leave the Azerbaijan province. The

\footnotetext{
${ }^{16}$ Martin Sicker, The Bear and the Lion: Soviet Imperialism and Iran” Freager New York, 1998. Persia's territories lost to Russia in the war were: present day Republic of Azerbaijan, Daghestan, Amenia, Eastern Gorgia, Igdir, Khanate of Erevan and Nakhchivan.
} 
historiography of the Azerbaijan crisis is often described as the genesis of the Cold War. ${ }^{17}$ (Blake, 2009; Fawcett, 1992). In short, Iran and Russia continued to experience difficulties in their relationship until the collapse of the Soviet Union in 1991.

\section{Since the post-Soviet era}

For Moscow, unlike for Washington, the Iranian revolution was a good and propitious development. Initially, Moscow had hoped the strong anti-American sentiments that prevailed in Iran at the time would serve as a catalyst for strong economic, political and even perhaps military cooperation between the two countries. The bad news, however, was that shortly after the revolution, the Ayatollah Ruhollah Khomeini expressed only a slightly better view of the Soviet Union than he had expressed about the U.S. To him, the Soviet Union was also a 'Satan' but a lesser one. The Iranians, too, must have felt ambivalent and unsure about the demise of the Soviet Union in 1991. On the one hand, an old, powerful and aggressive neighbour had disintegrated; on the other, the vanishing of a superpower had left the Iranians unprotected and exposed to the mercy of an equally aggressive superpower. Rightly or wrongly, Washington had from day one shown little understanding of, or sympathy towards the Iranian revolution. At the time, Iran had been a target of Washington for more than a decade and Teheran felt very vulnerable to the latter's undisguised plan of regime change. Washington's plan to bring down the Islamic Republic appeared now much easier to put into effect. In short, Iran was left with no major world power to shield it from the whims of the sole superpower.

Yet at the very time of its vulnerability, the Islamic Republic was feeling rather confident of itself for two reasons. The first was that it had withstood eight years of war with Iraq, despite the fact that the latter had received very generous assistance in military, intelligence and propaganda from the West, as well as financial assistance from Saudi Arabia and Kuwait. The second was that the war had taught the Iranian leadership that they had to shed much of their earlier ideologically driven foreign policy in favour of pragmatism and political realism. The partial shedding of Islamic ideology helped Teheran to put to good use the managing of a new relationship with Russia and the newly established independent Muslim states in the Caucasus and Central Asia. Persia/Iran has had long historical, political and cultural ties with many of

\footnotetext{
${ }^{17}$ Kristen Blake, "The U.S.-Soviet Confrontation of Iran, 1945,1962: A Case in the Annals of the Cold War," 2009. See also Louise I. Fawcett, "Iran and the Cold War: The Azerbaijan Crisis of 1946. 1991, Cambridge Middle East Library, 1991, 26.
} 
the former Soviet republics. Shortly after the breakup of the Soviet Union, some of these states plunged into territorial disputes, ethnic tensions and even wars. When a war broke out between the republics of Christian Armenia and Muslim Azerbaijan in the 1990s (the war again fared up between them in September 2010), Iran showed its pragmatism in action in foreign policy. It could have exploited tensions and inflamed the war between the two countries by supporting, say, Azerbaijan, thus causing an unnecessary headache for Russia. But Teheran refrained from doing so. and sided with Christian Armenia. The war, however, cost Iran greatly when 100,000 war refugees from Azerbaijan fled to Iran, and remained there until the end of the hostility between Baku and Eravan. ${ }^{18}$ Similarly, Iran adopted a neutral stance in the conflict between Russia and Muslim Chechnya in the 1990s. In other words, Iran did not take advantage of Russia's political difficulties at the time of crises in the former Soviet republics.

\section{Russia and Iran during Yeltsin's era}

In the early years of the post-Cold War era, Russia, under the presidency of Boris Yeltsin, had adopted a dual policy when it came to choosing between Teheran and Washington. Put it simply, Moscow bet both ways, depending on which side its national interests rested. In effect, Yeltsin played what in international relations is called political realism, that is to say, when disputes are settled between a great power and a lesser power, it is almost always the latter's interests that are sacrificed at the altar. Or to put it differently, when Russia came to choose between the U.S. and Iran, Yeltsin mostly sided with Washington. For instance, U.S. Vice President Al Gore and Russian Prime Minister Viktor Chernomyrdin signed an agreement in 1995 in which Russia agreed to limit the amount of arms sales and nuclear technical knowhow that it provided to the time trying to 'reset...U.S.-Russia relations. ${ }^{19}$ By the mid-1990s, Russia's one-sided policy of favouring Washington over Teheran had somewhat changed, and Moscow began to show greater interest in engaging Iran constructively and cooperatively. For example, in 1995, Teheran had asked Moscow to help it to rebuild Iran's nuclear facilities for producing energy for civilian purposes at Bushehr, on the Persian Gulf. As a matter of historical record, it should also be noted that the Bushehr plant had been built by West Germany in the 1970s.

\footnotetext{
${ }^{18}$ Adam Tarock, Iran and Russia in Strategic Alliance," Third World Quarterly, 1997, Vol. 18, No.2, 216.

${ }^{19}$ Elizabeth Alexander, "Building on the Reset: The Vice President in Moscow," The White House Press Release, 10 March 2021.
} 
Russia agreed, however, to provide the technical assistance required and to reset its nuclear programme and make it fully operational. But when President Bill Clinton asked President Yeltsin to abandon the agreement with Iran the latter refused. That was a great and delightful surprise to the Iranians because in previous years Russia seemed to have resigned itself to playing a secondary role on the international stage. Iran was also happy with Russia's argument when it rejected the U.S. request. Russia's argument was that in rebuilding Iran's nuclear facilities, Moscow was doing nothing different from what Washington was doing in arranging for North Korea to obtain a reactor, and that the U.S. was providing Pakistan with very sophisticated weapons - even though Pakistan had neither signed the Non-Proliferation Treaty, nor, unlike Iran, had it allowed inspections of its nuclear programme by the International Atomic Energy Agency (IAEA). Russia's decision was also based on economic considerations. Moscow was attracted to the multimillion dollars worth Bushehr project, and Moscow's economy was then in a dire need of money. According to Bulmer-Thomas, in the early 1990s, Russia not only had lost its mighty empire, it was also in danger of losing its sovereignty because of its very bad economic situation. ${ }^{20}$ A pseudo-partnership and friendship had then developed between presidents Yeltsin and Bill Clinton, with the U.S. taking advantage of Russia's political and economic weaknesses ${ }^{21}$ The Russian economy had nearly collapsed as a result of a painful shift from a planned economy to a market economy. Yet, despite all the economic difficulties Moscow was facing, it delayed the rebuilding of the Bushehr plant for a long time. The delays could be attributed to Russian's attempt, up to the mid- 1990s, to keep a healthy balance in its relations between Teheran and Washington. To conclude the Bushehr story, the reconstruction of it was completed in 2007, and was finally commissioned in 2017. Better news was awaiting the Iran-Russia new ties.

\section{In the age of Putin}

President Vladimir Putin may be a 'killer,' according to President Biden, but in Teheran he is warmly welcomed and embraced as a 'reliable' partner. Perhaps it is no exaggeration to say that in the centuries-old relationship between the two countries, their relations have never been as good as it has been in Putin's era. Under his leadership, their cooperation in trade, technology, military and political have been greatly expanded. When Putin took office in May

\footnotetext{
${ }^{20}$ Victor Bulmer-Thomas, Empire In Retreat: The Past, and Future of the United States, Yale University Press, 2018, 231.

${ }^{21}$ Chris Hedges, "Manufacturing War with Russia," www.commondreams, org 3 June 2019.
} 
2012, he soon began working with his Iranian counterpart, President Hassan Rouhani. Between August 2013 and February 2015, he met the Iranian president four times. And since then, there have been frequent visits between high-ranking officials of the two countries. In fact, the success of their cooperation was so encouraging that during one of Putin's many visits to Teheran, the Ayatollah Ali Khamenei reportedly told him that Iran and Russia should hence work closer together to isolate the United States in the Middle East. ${ }^{22}$ To appreciate the significance of and to illustrate how much Iran's foreign relations have shifted from the West to the East, we need to place the ayatollah's remarks into historical context.

Iran had almost unreservedly sided with the U. S., perhaps more than other Middle Eastern states had. After the Cold War, Russia, which had for decades built good networks for influence in the region, retreated from the region. For the first few years thereafter, Moscow was in no position - economically, politically and militarily - to influence political developments in the region, which had become the exclusive U.S. sphere of influence. But President Putin has since managed to recapture much of the influence that Russia enjoyed in the Middle East prior to the collapse of the Soviet Union. Shorn of its past imperial grandeur and Soviet superpower status which inspired fear in the region, as well as elsewhere, the new Russia did infuse very little fear in Iran. And being isolated and shunned by the West for decades, the Islamic Republic welcomed and supported Russia's active return there. Syria is a good example of that. It is well known that among Middle East countries, Iran was the first one that support Syria's President Bashir Al Assad when he faced an internal crisis in March 2011. Iran's assistance alone could not save Damascus from defeat by the Syrian rebels, so Teheran apparently encouraged Moscow to return actively to the Middle East. Russia did, but of course for its own geopolitical interests. The two countries' engagement in Syria can be described as the most significant military cooperation between the two.

Neither Teheran nor Moscow, when getting embroiled in the Syrian crisis, could have been under any illusion that their involvement there would be without risks. After all, by then the Syrian conflict had already been 'internationalised,' in that the U.S., France, Saudi Arabia and Qatar had already entangled themselves in the conflict. But for both Iran and Russia the preservation of Syria as a single entity, with President Bashir Al Assad maintaining his position, was crucial, geo- strategically speaking. The victory of the Syrian opposition groups would have further enhanced Washington's influence in the region, a development that would

\footnotetext{
${ }^{22}$ Denis Pinchuck, "Iran and Russia Should Isolate the U.S. in the Middle East," The Age (Melbourne), 2017, 14.
} 
have greatly weakened Iran's and Russia's positions in the region. For Iran in particular, maintaining the status quo in Syria was a matter of very high importance, as Syria was, and is, considered a defensive line against Israel's potential attacks on Hezbollah in Lebanon, and/or eventually against Iran. In addition, for Iran, Syria's security and sovereignty has always carried sentimental value. After all, Syria had been the only Arab country that had steadfastly sided with the Islamic Republic. During the Iran-Iraq war and after, Syria supported Iran unreservedly. For that, Teheran felt, and feels eels, 'morally indebted' to Syria. For Russia, the fall of the Assad government would have deprived it of its naval base in Torus in Syria. The port has been Russia's only naval facility in the Middle East in the post-Cold War era. Losing the naval base there, would have amounted to leaving to the U.S., Moscow's very important naval base in the Middle East. Putting aside the issue of Syria for a moment, there are other ways that the Islamic Republic can contribute to Russia's strategic position in the region; help Moscow to play a role as 'peacemaker;' offer opportunities for Russian arms sales in the region; they include assisting Russia in its fight against Muslim fundamentalism in Central Asian republics.

Aa pointed out earlier, much has been said about the Syrian crisis over the years; what should be added here is that while Teheran's and Moscow's plans have been to maintain the status quote in Syria, it does not necessarily follow that their political and strategic objectives have been quite the same. For the Iranian leadership, the active return of Russia to the Middle East was, and remains, important in the sense that Russia, although not of equal weight to the United States, nevertheless carries considerable political and military weight in the international arena, and, therefore, it is a counterweight to U.S. power in the region. Teheran appears to have placed Russia in its 'special foreign policy basket'. For Russia, Iran's partnership is significant. True that Russia enjoys good relationships with other major Middle Eastern countries such as Saudi Arabia, Jordan, Egypt, Kuwait and Israel. But many of these states are under the U.S. influence and are likely to remain so for the forceable future. Iran on the other hand, is the only country in the region that has been following an independent foreign policy, though of necessity leaning towards Russia and China. In short, since Putin's ascendency he has played a pivotal and determining role in expanding and strengthening Russia's relations with Iran. And the more the West, in particular the U.S. puts political and economic pressure on Russia, the more the latter values its good relations with Iran. Given all the above, it is reasonable to think that Iran's close ties with Russia (and China) are the byproduct of Washington's hostile policy towards the three of them. 


\section{The Dilemmas for Russia and China}

Although the Islamic Republic of Iran enjoys a good working relationship with both Beijing and Moscow, the latter two find it difficult to balance their relationships with Iran when it comes to honouring, their obligations under the JCPOA, to which they are signatories. Under the agreement, the two big powers are obligated to trade with Iran without restrictions. However, the U.S. sanctions on Iran have posed a real dilemma for both of them. For when honouring the JCPOA terms, they at the same time are taking a stand contrary to their own interests when it comes to -their relationships with the U.S. (The European signatories of the JCPOA do not have that dilemma, for although they have disagreed with the U.S. sanctions, they have continued to follow Washington on this issue.) Relations between China/Russia and the U.S. have in more recent years deteriorated. This, in turn, has helped, to the delight of the Iranians, the expansion of trade relations with the two countries mentioned above. For example, both countries have much at stake in Iran's energy sector and investments in its energy development projects. Although importation of oil from Iran is not as vital for Russia as it is for China, Moscow's investments in and trade with Iran are crucial for the Russian economy. But Iran's other economic attractions include huge potential for foreign investors, a big market (eighty-two million people), sales of new technologies and weapons. These are things that China and Russia would find hard to resist So, for them the question of whether or not to comply with Washington's sanctions against Iran has put their partnership with Teheran to a real test. To conclude, both countries, it seems, have decided not to comply fully with Washington's demands on sanctions against Iran.

Having said all that Russia, may find it more difficult than China to ignore the U.S sanctions policy on Iran, for it is more vulnerable to outside political and economic pressure, than Beijing. For instance, if Russia, or any other country, decided to import Iranian oil, the U.S. could go to the extreme and escalate the conflict by blockading and/or seizing ships carrying Iranian oil to countries that the U.S. disapproves of. In fact, an Iranian oil-tanker, reportedly headed for Syria, was seized by Britain in Gibraltar in mid-July 2019.The seizure took place apparently under pressure from the U.S. Iran had already predicted the possibility of such action. But an oil tanker carrying Iranian oil to Beijing is much less likely to face the same fate as would oil tankers carrying Iranian oil to Moscow or any other country. 


\section{Conclusion}

The geostrategic partnership between Iran, Russia and China may not have come about, or if it had, may not have become such an important issue in international politics today, had it not been for the U.S. hostility towards the three countries. That hostility has, it should be noted, continued, if not escalated, under President Joe Biden. The U.S. the hardline stance towards the three counties has also negatively impacted on the relations between the U.S. and its Western allies, although the allies have mostly accepted and followed Washington's leadership. Truth is that Washington has abrogated to itself an exceptional and privileged position in the conduct of international affairs since the end of World War II and particularly since the end of the Cold War. Truth is also that the Trump administration, more than any of its predecessors, has claimed privileges for the U.S. Victor Bulmer-Thomas has captured this aspect of U.S. foreign policy concisely and elegantly:

The end of the Cold War removed many of the constraints that had previously held back the United States from intervening abroad. As a result, interventions have been frequent under all administrations since 1990. All five presidents (Bush Sr., Clinton, Bush Jr., Obama and Trump) have used both multilateral and unilateral forms of intervention, and none of them has been unduly concerned whether their actions were consistent with international law. While there have undoubtedly been differences in the approach taken to intervention by each president, none has questioned the imperial project and the conviction that the United States is the world's leader. The "golden rule" for U.S intervention has been multilaterally through the U.N. and therefore with the blessing of international law. ${ }^{23}$ Or, one might add, without the blessing of international institutions.

Among the privileges that the Trump administration frequently claimed is the concept of "unilateralism". This concept had become highly contentious and has become a serious issue in world diplomacy. Good examples of that include Washington's unilateral actions in relation to the withdrawal from the Trans-Pacific Partnership, the Paris Climate Accord, the Iran nuclear deal and the scrapping of the landmark Intermediate Range Nuclear Forces Treaty signed with Russia during the Cold War. None of President Trump's predecessors had so cavalierly and high-handedly used unilateralism as a tool in foreign policy, as he has used it when dealing with Russia, China and Iran. Trump's policy towards Teheran had been particularly uncompromising. And Iran's position, based on its past experiences with the U.S.,

\footnotetext{
${ }^{23}$ Bulmer-Thomas, 2018, 23-28.
} 
is not to give in to Washington's political and economic pressures. As Ayatollah Ali Khamenei has put it, 'We believe our problems cannot be resolved by negotiations with the U.S., and no free nation would ever accept negotiating under pressure'24 (Hiro, 2019). Anyway, in case of a military confrontation between Teheran and Washington (unlikely), Beijing and Moscow would most likely refrain from getting involved on the side of Teheran. But through the U.N. and other international forums, they could make it difficult for Washington to legitimise a war against Iran as they did in the case of war against Libya in 2011.

Finally, it would not be unduly optimistic to believe that China and Russia would continue, however limited in scope, to trade with Iran and support it to enable it to resist U.S. maximum pressure. The survival of the Islamic Republic may not be vital for the national interests of either Moscow or Beijing, but the existence of the present political system in Iran is certainly very crucial for the interests of the other two partners. As for Iran, as long as the U.S. hostility towards the country continues, which is very likely, increased geopolitical tension and economic war between Moscow/Beijing and the U.S. serves Teheran well. In other words, the thread that has bonded the trio together is the threat that they feel is facing them from the United States.

\section{References}

[1] -Susan Watkins, in New Left Review, “America vs China,” 2019, No. 115, 1.

[2] - Ghlam Reza Afkhami, Life of the Shah, University of California Press, 2009, 296.

[3] Afkhami, The Life of, 206.

[4] Scott Harold and Alireza Nader, "China and Iran: Economic. Political and Military Cooperation,; RAND Corporation, Centre for Middle East Public Policy, 2012, p.

[5] Alexander Kukin, "Have We Past the Peak of Sino-Russian Rapprochement," The Washington Quarterly, September 2021, 137.

[6] Harold and Nader, 2012, 3.

[7] Esfandyar Batmangholidj, "China Restarts Purchase Iranian Oil: Bucking Trump' s Sanctions." Bourse and Bazaar," :twitter.com ,17 June 2019.

[8] United States Institute of Peace, "Last Among Equals," (the Iran primer), 6 October 2020.

\footnotetext{
${ }^{24}$ Dilip Hiro, "Under Trump, America's Global Standing at Record Low," www.counterpunchh.org 1July
} 2019. 
[9] Jon B. A. Alterman, "Chines and Russian Influence in the Middle East," Middle East Policy, Vol. 26, No.2, 2019.

[10] Iran Daily, "Official: Iran-China Trade to Reach \$24 Billion in 2018," 11 September 2018

[11] Dina Esfandiary and Ariane Tabatabai, Moscow and Bejing Have Teheran's Back," Foreign Policy, 26 July 2018.

[12] Juan Cole, "How Trump Lost Iran to China -25 Years: Lion-Dragon Deal Makes Iran Part of One Belt, One Road," www.informedcomments.org 7 August 2020.

[13] Susan Fayazmanesh, “ The U.S. Sanctions Are Affecting All Aspects of Iranian Life in Iran," www.counterpuch.org 1 August 2019.

[14] Harold and Nader, 2012.

[15] Pars News Agency, "Senior Analyst Underline's Irn's Geostrategic Importance to China," 20 June 2021.

[16] Martin Sicker, The Bear and the Lion: Soviet Imperialism and Iran" Freager New York, 1998. Persia's territories lost to Russia in the war were: present day Republic of Azerbaijan, Daghestan, Amenia, Eastern Gorgia, Igdir, Khanate of Erevan and Nakhchivan.

[17] Kristen Blake, "The U.S.-Soviet Confrontation of Iran, 1945,1962: A Case in the Annals of the Cold War," 2009. See also Louise I. Fawcett, "Iran and the Cold War: The Azerbaijan Crisis of 1946. 1991, Cambridge Middle East Library, 1991, 26.

[18] Adam Tarock, Iran and Russia in Strategic Alliance," Third World Quarterly, 1997, Vol. 18 , No.2, 216.

[19] Elizabeth Alexander, "Building on the Reset: The Vice President in Moscow," The White House Press Release, 10 March 2021.

[20] Victor Bulmer-Thomas, Empire In Retreat: The Past, and Future of the United States, Yale University Press, 2018, 231.

[21] Chris Hedges, "Manufacturing War with Russia," www.commondreams, org 3 June 2019.

[22] Denis Pinchuck, "Iran and Russia Should Isolate the U.S. in the Middle East," The Age (Melbourne), 2017, 14.

[23] Bulmer-Thomas, 2018, 23-28.

[24] Dilip Hiro, “Under Trump, America 's Global Standing at Record Low, " www.counterpunchh.org 1July 2019. 